\title{
PERILAKU CARING PERAWAT DENGAN TINGKAT KEPUASAN PASIEN di RSUD H. ANDI SULTHAN DAENG RADJA KAB. BULUKUMBA
}

\author{
${ }^{1}$ Haerani \\ ${ }^{2}$ Haerati
}
${ }^{1}$ Departemen Keperawatan Manajemen Stikes Panrita Husada Bulukumba
${ }^{2}$ Departemen Keperawatan Dasar Stikes Panrita Husada Bulukumba

\begin{abstract}
Alamat Korespondensi:
Ns.Haerani,S.Kep,M.Kep

Program Studi Profesi Ners

Sekolah Tinggi Ilmu Kesehatan Panrita Husada

Bulukumba, 04132514721

HP: 085299970570

Email:ainunhaerani@yahoo.com
\end{abstract}




\begin{abstract}
ABSTRAK
Fenomena yang sekarang terjadi banyak perawat yang kurang memperhatikan keamanan dan kenyamanan serta tidak peduli dengan keluhan-keluhan pasien sehinggga pasien kurang puas dalam pelayanan keperawatan yang diberikan. Penelitian ini bertujuan mengetahui hubungan perilaku caring perawat dengan tingkat kepuasan Pasien di ruang perawatan Seruni di RSUD H. A. Sulthan Dg Radja Kabupaten Bulukumba. Jenis penelitian ini merupakan penelitian observasional analitik dengan pendekatan "cross sectional".sampel sebanyak 96 orang pasien rawat inap Seruni. Pengambilan sampel pada penelitian ini dilakukan dengan teknik non probablility sampling dengan consecutive sampling. Pengumpulan data dilakukan melalui observasi, kuesioner, dan dokumentasi. Data dianalisis dengan Chi-Square. Hasil analisis Chi-Square menunjukkan bahwa terdapat hubungan antara perilaku caring perawat dengan tingkat kepuasan pasien $(p=0,001)$. Hasil analisis kekuatan hubungan menunjukkan arah korelasi positif dengan kekuatan korelasi kuat.
\end{abstract}

\title{
Kata kunci: Perilaku Caring, Kepuasan Pasien
}

\begin{abstract}
ABSTRAC
The phenomenon that is happening now is that many nurses pay little attention to safety and comfort and are not concerned with patient complaints so that patients are less satisfied in the nursing services provided. This study aims to determine the relationship of nurses caring behavior with the level of patient satisfaction in the Seruni care room at H. A. Sulthan Hospital Dg Radja Bulukumba Regency. This type of research is an analytic observational study with a "cross sectional" approach. Samples were 96 inpatients in Seruni. Sampling in this study was conducted with non-probability sampling techniques with consecutive sampling. Data collection is done through observation, questionnaires, and documentation. Data were analyzed with Chi-Square. The results of the Chi-Square analysis showed that there was a relationship between nurses' caring behavior and patient satisfaction $(p=0.001)$. The results of the analysis of the strength of the relationship indicate the direction of a positive correlation with the strength of a strong correlation.
\end{abstract}

\section{Keywords: Caring Behavior, Patient Satisfaction}




\section{PENDAHULUAN}

Mutu pelayanan keperawatan sebagai indikator kualitas pelayanan kesehatan menjadi salah satu faktor penentu citra institusi pelayanan kesehatan di mata masyarakat. Salah satu indikator dari mutu pelayanan keperawatan itu adalah apakah pelayanan keperawatan yang diberikan itu memuaskan pasien atau tidak.

Salah satu faktor yang mempengaruhi kepuasan pasien adalah pelayanan keramahan petugas rumah sakit, kecepatan dalam pelayanan. Institusi pelayanan kesehatan dianggap baik apabila dalam memberikan pelayanan lebih memperhatikan kebutuhan pasien. Kepuasan muncul dari kesan pertama masuk pasien terhadap pelayanan keperawatan yang diberikan.

Caring merupakan fenomena universal yang berkaitan dengan cara seseorang berpikir, berperasaan, dan bersikap ketika berhubungan dengan orang lain. Dalam memberikan asuhan, perawat menggunakan keahlian, kata-kata yang lemah lembut, sentuhan, memberikan harapan, selalu berada di samping klien, dan bersikap caring sebagai media pemberi asuhan.

Rahmawati R (2015), mengatakan bahwa 'fenomena yang sekarang terjadi banyak perawat yang kurang memperhatikan keamanan dan kenyamanan serta tidak peduli dengan keluhan-keluhan pasien sehinggga pasien kurang puas dalam pelayanan keperawatan yang diberikan".

Rumah Sakit Umum Daerah H. Andi Sulthan Daeng Radja merupakan satusatunya rumah sakit di Kabupaten Bulukumba, yang digunakan sebagai tempat rujukan dari puskesmas yang ada di Kabupaten tersebut. Rumah sakit ini sering kali mendapat complaint atas mutu pelayanan yang diberikan.

Hasil wawancara menunjukkan dari 20 orang pasien yang menjalani rawat inap, 14 diantaranya mengeluh kurang puas dengan pelayanan yang diberikan oleh perawat karena perawat yang memberikan pelayanan kurang menunjukkan perilaku caring. Mereka mengatakan perawat yang memberikan pelayanan terkadang tidak memperkenalkan diri, kurang ramah, jarang memberi informasi sebelum melakukan tindakan, kurang tanggap, terkesan kurang peduli dan tidak responsif terhadap keluhan pasien.

Fenomena tersebut diatas pada umumnya menunjukkan adanya kecenderungan sikap dan perilaku perawat yang tidak caring terhadap pasien yang memengaruhi kualitas asuhan keperawatan dan berdampak pada tingkat kepuasan pasien, namun survei yang dilakukan tentang tingkat kepuasan pasien yang telah 
dilakukan masih bersifat umum, belum secara maksimal mengeksplorasi tentang perilaku caring perawat dalam berinteraksi dengan pasien.

Tujuan penelitian ini adalah untuk mengetahui hubungan perilaku cering perawat dengan tingkat kepuasan pasien di ruang perawatan Seruni RSUD H.A. Sulthan dg Radja Babupaten Bulukumba.

\section{METODE}

Jenis penelitian ini merupakan penelitian observasional analitik dengan pendekatan "cross sectional". Penelitian cross sectional adalah jenis penelitian yang menekankan waktu pengukuran/observasi data variabel independen dan dependen hanya satu kali pada satu saat (Nursalam, 2013). Penelitian ini bertujuan untuk mengetahui hubungan perilaku caring perawat dengan tingkat kepuasan pasien di ruang perawatan Seruni RSUD H. A. Sulthan dg Radja kabupaten Bulukumba.

Populasi merupakan keseluruhan sumber data yang diperlukan dalam suatu penelitian (Saryono \& Anggraeni, 2013). Populasi dalam penelitian ini adalah pasien yang dirawat di ruang perawatan Seruni berjumlah 131 orang.

Penarikan sampel menggunakan teknik non probablility sampling dengan consecutive sampling . Jumlah sampel dalam penelitian ini adalah 96 responden.
Pengumpulan data dilakukan oleh peneliti dengan menggunakan kuesioner, wawancara, serta observasi untuk mengukur perilaku caring perawat dan tingkat kepuasan pasien di ruang perawatan seruni RSUD H. A. Sulthan dg Radja kabupaten Bulukumba. Kuesioner yang digunakan sebelumnya telah memenuhi syarat uji validitas dan reliabilitas.

Data dianalisis berdasarkan skala ukur dan tujuan penelitian dengan menggunakan perangkat lunak program komputerisasi. Data dianalisis secara : (1). Analisis Univariat, Analisis dilakukan untuk melihat proporsi. (2). Analisis Bivariat, Uji bivariat dilakukan untuk mencari hubungan antara variabel independen dan variabel dependen dengan uji yang digunakan adalah chi-square bila memenuhi syarat, dan akan dilakukan uji fisher's exact sebagai alternative. Interval kepercayaan yang diambil adalah 95\% dan batas kemaknaan yang diterima apabila $\mathrm{p}$ $<0,05$.

\section{HASIL}

Distribusi Frekuensi Responden berdasarkan kelompok umur di RSUD. H. A. Sulthan Daeng Radja Tahun berdasarkan tabel 1 menunjukkan bahwa responden terbanyak adalah responden usia 26-50 tahun sebanyak 51 orang 
$(53.1 \%)$, jenis kelamin responden hampir berimbang jumlahnya, laki-laki sebanyak 49 orang $(51 \%)$ dan perempuan sebanyak 47 orang (49\%), sebagian besar belum menikah sebanyak 53 orang (55.2\%), sebagian besar dengan tingkat pendidikan SMA sebanyak 55 orang (57.3\%), sebagian besar responden dengan lama perawatan 3-6 hari yaitu sebanyak 86 orang $(89.7 \%)$.

Berdasarkan Tabel 2 di atas menunjukkan bahwa persepsi responden tentang perilaku caring perawat lebih banyak dengan kategori baik yaitu sebanyak 73 orang $(76,0 \%)$.

Berdasarkan Tabel 3 di atas menunjukkan persepsi tingkat kepuasan responden lebih banyak terdapat pada kategori puas yaitu 73 orang $(76,0 \%)$.

Hubungan perilaku caring perawat dengan tingkat kepuasan pasien di ruang perawatan seruni RSUD H. A. Sulthan Daeng Radja Kabupaten Bulukmba.

Berdasarkan 4 menunjukkan hubungan antara perilaku caring perawat dengan tingkat kepuasan pasien di ruang perawatan seruni RSUD H. A. Sulthan Daeng Radja Kabupaten Bulukumba Tahun 2016 menunjukkan bahwa dengan perilaku caring perawat yang baik maka sebagian besar pasien merasa puas yaitu 68 orang (93.15\%), begitu pula dengan perilaku caring perawat yang kurang baik maka sebagian besar pasien merasa kurang puas yaitu 18 orang $(78,26 \%)$. Hasil uji statistik didapatkan nilai $\mathrm{p}=0,001$ ( $\mathrm{p}$ $<0,05)$ maka dapat disimpulkan bahwa terdapat hubungan antara perilaku caring perawat dengan tingkat kepuasan pasien di ruang perawatan seruni RSUD $\mathrm{H}$. A. Sulthan Daeng Radja Kab. Bulukumba tahun 2016.

Berdasarkan tabel 5 menunjukkan bahwa korelasi antara perilaku caring perawat dengan tingkat kepuasan pasien adalah bermakna. Nilai korelasi spearmen sebesar 0,753 menunjukkan bahwa arah korelasi positif dengan kekuatan korelasi kuat.

\section{PEMBAHASAN}

Berdasarkan hasil analisis menggunakan uji statistik chi square diperoleh nilai $\rho=0,001<\alpha=0,05$. Berdasarkan hasil tersebut dapat disimpulkan bahwa terdapat hubungan perilaku caring perawat dengan tingkat kepuasan pasien di ruang perawatan seruni RSUD H. Andi Sulthan Daeng Radja Kab. Bulukumba tahun 2016.

Hasil penelitian tersebut sejalan dengan hasil penelitian Abdul (2013) dengan judul penelitian: Hubungan Perilaku Caring Perawat Dengan Tingkat Kepuasan Pasien Rawat Inap Rumah Sakit. Hasil penelitian menunjukkan bahwa ada hubungan signifikan antara perilaku caring perawat dengan tingkat 
kepuasan pasien rawat inap. Dijelaskan pula bahwa perilaku caring perawat adalah salah satu aspek yang berhubungan dengan pelayanan keperawatan, karena caring mencakup hubungan antar manusia dan berpengaruh terhadap mutu pelayanan dan kepuasan pasien. Semakin baik perilaku caring perawat dalam memberikan pelayanan asuhan keperawatan, pasien atau keluarga semakin senang dalam menerima pelayanan, berarti hubungan terapeutik perawat-klien semakin terbina.

Penelitian Denys Yanuar Wicaksono dengan judul Kiat Keperawatan (Caring) Dalam Meningkatkan Mutu Asuhan Keperawatan. Dalam penelitian ini dikatakan bahwa Puas atau tidaknya pasien dan penilaian baik atau buruknya terhadap kualitas pelayanan keperawatan sangat bergantung pada bagaimana seorang perawat mengaplikasikan kiat caring ketika memberikan pelayanan keperawatan. Hal inilah yang dapat mempengaruhi kepercayaan masyarakat terhadap sebuah rumah sakit, yang nantinya juga akan mempengaruhi jumlah pasien di instalasi rawat inap rumah sakit tersebut.

Menurut klinis (2007) dalam Nursalam (2014), Ada beberapa faktor yang mempengaruhi kepuasan pasien, yaitu kualitas produk atau jasa, harga, emosional, kinerja, estetika, karakteristik produk, pelayanan, lokasi, fasilitas, komunikasi, suasana, dan desain visual.

\section{KESIMPULAN DAN SARAN}

Berdasarkan hasil penelitian diatas maka disimpulkan bahwa terdapat hubungan yang signifikan antara perilaku caring perawat dengan tingkat kepuasan pasien di ruang perawatan seruni RSUD $H$. Andi Sulthan Daeng Radja Kab. Bulukumba tahun 2016. Hasil penelitian ini hendaknya dapat menjadi informasi yang berguna untuk meningkatkan kualitas pelayanan keperawatan terutama perilaku caring perawat dalam meningkatkan kepuasan pasien.

\section{DAFTAR PUSTAKA}

Abdul, et al. (2013). Hubungan Perilaku Caring Perawat Dengan Tingkat Kepuasan Pasien Rawat Inap Rumah Sakit : Jurnal.

Aziz, abdul. (2012). Analisis Tingkat Keputusan Pasien Terhadap Pelayanan Keperawatan Prima di RSUP DR. M. Djamal Padang. Fakultas Keperawatan Universitas Andalas. Jurnal.

Damayanti, Denidya. (2013). Buku Pintar Perawat Propfesional Teori \& Praktik Asuhan Keperawatan. Mantra Books : Yogyakarta..

Hafsyah, Laila. (2012). Hubungan Perilaku Caring yang Dilakukan Perawat dengan Tingkat Klien di 
Ruangan Penyakit Dalam RSUD

Pariaman Tahun 2012. Skripsi

tidak diterbitkan. Padang : Fakultas

Keperawatan Universitas Andalas

Padang.

Hidayat, A. Aziz Alimul. (2014). Metode

Penelitian Keperawatan dan

Teknik Analisis Data. Salemba

Medika : Jakarta.

Indrastuti, Yani. (2010). Analisis

Hubungan Perilaku Caring dan

Motivasi dengan Kinerja Perawat

pelaksana Menerapkan Prinsip

Etik Keperawatan dalam Asuhan

Keperawatan di RSUD Sragen :

Tesis tidak diterbitkan. Depok :

Fakultas Ilmu Keperawatan

Magister Ilmu Keperawatan

Kekhususan Kepemimpinan dan

Manajemen Keperawatan.

Jahid, Halimah, et al. (2013). Faktor yang

Berhubungan dengan Kepuasan

Pasien Peserta Jamkesmas pada

Ruang Rawat Inap di Rumah sakit

elim Rantepao Kabupaten Toraja

Utara. Bagian AKK Fakultas

Kesehatan Masyarakat Universitas

Hasanuddin : Jurnal.

Keluarga Pasien Keluhkan Pelayanan

RSUD. (17 Februari, 2015). Radar

Selatan. Hal. 01.

Khairani, Laila. (2011). Faktor Faktor

Yang Mempengaruhi Kepuasan
Pasien Rawat Jalan RSUD

Pasaman Barat : Jurnal.

Notoatmodjo, Soekidjo.

(2012).

Metodologi Penelitian Kesehatan.

PT. Rineka Cipta : Jakarta.

Nursalam. (2013). Metodologi Penelitian

Ilmu Keperawatan: Pendekatan

Praktis. Edisi 3. Salemba Medika : Jakarta.

Nursalam. (2014). Manajemen

Keperawatan: Aplikasi dalam

Praktik Keperawatan Profesional.

Edisi 4. Salemba Medika : Jakarta.

Prabowo, et al. (2014). Hubungan Tingkat Kognitif Perawat tentang Caring dengan Aplikasi Praktek Caring di Ruang Rawat Inap RSU dr. H. Koesnadi Bondowoso. Volume 2 No. 1 Edisi Januari 2014.

Rosyidi, Kholid. (2013). Manajemen Kepemimpinan Dalam

Keperawatan. TIM : Jakarta.

Rahman, Melinda. (2014). Hubungan Persepsi Perilaku Caring Perawat Dengan Loyalitas Pasien Rawat Inap Kelas Iii Rumah Sakit Paru Jember. Skripsi tidak diterbitkan. Jember : Program studi Ilmu Keperawatan Universitas Jember.

Sandra, Rona. (2013). Hubungan Komunikasi Terapeutik Perawat Dengan Kepuasan Pasien Di Ruang Instalasi Rawat Inap Non Bedah (Penyakit Dalam Pria Dan 
Wanita) Rsup Dr. M. Djamil

Padang Tahun 2013 : Jurnal.

Saryono dan Anggraeni. (2013).

Metodologi Penelitian Kualitatif dan Kuantitatif dalam Bidang

Kesehatan. Yogyakarta: Nuha Medika.

Sugiyono. (2014). Statistika untuk Penelitian. Alfabeta : Bandung.

Tanjung, Noviyanti \& Salbiah. (2012). Harapan Pasien Dalam Kepuasan Perilaku Caring Perawat di RSUD Deli Serdang Lubukpakam. Fakultas Keperawatan Universitas Sumatra Utara : Jurnal.

Triwibowo, Cecep. (2013). Manajemen Pelayanan Keperawatan di Rumah Sakit. TIM : Jakarta.

Wawan, A dan Dewi M. (2010). Teori dan Pengukuran Pengetahuan, Sikap, dan Perilaku Manusia. Nuha Medika: Yogyakarta.

Wicaksono, DenysYanuar dan Dian Prawesti. (2012). Kiat Keperawatan (Caring) Dalam Meningkatkan Mutu Asuhan Keperawatan. Volume 5 No. 2 Edisi Desember 2012. 
Tabel 1 Distribusi Frekuensi Karakteristik Responden

Di Ruang Perawatan Seruni RSUD H. Andi Sulthan Daeng Radja Kab. Bulukumba

\begin{tabular}{lcc}
\hline Karakteristik Responden & Frekuensi & Persentase (\%) \\
\hline Usia (tahun) & 43 & 44.8 \\
$17-25$ & 51 & 53.1 \\
$26-50$ & 2 & 2.1 \\
- 50 & & \\
Jenis kelamin & 49 & 51 \\
Laki - laki & 47 & 49 \\
Perempuan & & \\
Pendidikan & 35 & 36.5 \\
SMP & 55 & 57.5 \\
SMA & 3 & 3.1 \\
D III & 3 & 3.1 \\
S1 & & \\
Status pernikahan & 43 & 44.8 \\
Nikah & 53 & 55.2 \\
Belum nikah & & \\
Lama perawatan (hari) & 86 & 89.7 \\
3-6 & 7 & 7.2 \\
7 - 10 & 3 & 3.1 \\
D 10 & $\mathbf{9 6}$ & $\mathbf{1 0 0 \%}$ \\
\hline \multicolumn{2}{l}{ Jumlah }
\end{tabular}

Tabel 2. Distribusi Frekuensi Perilaku Caring Perawat

Di Ruang Perawatan Seruni RSUD H. Andi Sulthan Daeng Radja Kab. Bulukumba

\begin{tabular}{|c|c|c|}
\hline Perilaku Caring Perawat & Frekuensi (f) & $\begin{array}{l}\text { Persentase } \\
(\%)\end{array}$ \\
\hline Baik & 73 & 76.0 \\
\hline Kurang Baik & 23 & 24.0 \\
\hline Jumlah & 96 & 100 \\
\hline
\end{tabular}

Tabel 3. Distribusi Frekuensi Tingkat Kepuasan Responden

Di Ruang Perawatan Seruni RSUD H. Andi Sulthan Daeng Radja Kab. Bulukumba

\begin{tabular}{ccc}
\hline Tingkat Kepuasan & Frekuensi (f) & $\begin{array}{c}\text { Persentase } \\
(\boldsymbol{\%})\end{array}$ \\
\hline Puas & 73 & 76.0 \\
Kurang Puas & 23 & 24.0 \\
\hline Jumlah & $\mathbf{9 6}$ & $\mathbf{1 0 0}$ \\
\hline
\end{tabular}


Tabel 4

Analisis Hubungan Perilaku Caring Perawat Dengan Tingkat Kepuasan Pasien Di Ruang Perawatan Seruni RSUD H. Andi Sulthan Daeng Radja Kab. Bulukumba

\begin{tabular}{|c|c|c|c|c|c|c|c|}
\hline \multirow{3}{*}{$\begin{array}{c}\text { Perilaku Caring } \\
\text { Perawat }\end{array}$} & \multicolumn{6}{|c|}{ Tingkat kepuasan pasien } & \multirow{3}{*}{$\rho$} \\
\hline & \multicolumn{2}{|c|}{ Puas } & \multicolumn{2}{|c|}{ Kurang puas } & \multicolumn{2}{|c|}{ Total } & \\
\hline & $\mathrm{n}$ & $\%$ & $\mathrm{n}$ & $\%$ & $\mathrm{n}$ & $\%$ & \\
\hline Baik & 68 & 93.15 & 5 & 21.74 & 73 & 76.0 & \\
\hline Kurang Baik & 5 & 6.85 & 18 & 78.26 & 23 & 24.0 & 0.000 \\
\hline Total & 73 & 100 & 23 & 100 & 96 & 100 & \\
\hline
\end{tabular}

Tabel 5

Analisis Kekuatan Hubungan Perilaku Caring Perawat Dengan Tingkat Kepuasan Pasien Di Ruang Perawatan Seruni RSUD H. Andi Sulthan Daeng Radja Kab. Bulukumba

Tingkat Kepuasan Pasien

\begin{tabular}{ccc}
\hline Perilaku Caring & $r$ & 0.753 \\
Perawat & $p$ & 0.000 \\
& $n$ & 96 \\
\hline
\end{tabular}

